\title{
The Politics, Power, and Pathologies of International Organizations
}

\author{
Michael N. Barnett and Martha Finnemore
}

Do international organizations really do what their creators intend them to do? In the past century the number of international organizations (IOs) has increased exponentially, and we have a variety of vigorous theories to explain why they have been created. Most of these theories explain IO creation as a response to problems of incomplete information, transaction costs, and other barriers to Pareto efficiency and welfare improvement for their members. Research flowing from these theories, however, has paid little attention to how IOs actually behave after they are created. Closer scrutiny would reveal that many IOs stray from the efficiency goals these theories impute and that many IOs exercise power autonomously in ways unintended and unanticipated by states at their creation. Understanding how this is so requires a reconsideration of IOs and what they do.

In this article we develop a constructivist approach rooted in sociological institutionalism to explain both the power of IOs and their propensity for dysfunctional, even pathological, behavior. Drawing on long-standing Weberian arguments about bureaucracy and sociological institutionalist approaches to organizational behavior, we argue that the rational-legal authority that IOs embody gives them power independent of the states that created them and channels that power in particular directions. Bureaucracies, by definition, make rules, but in so doing they also create social knowledge. They define shared international tasks (like "development"), create and define new categories of actors (like "refugee"), create new interests for actors (like "promoting human rights"), and transfer models of political organization around the world (like markets and democracy.) However, the same normative valuation on impersonal, generalized rules that defines bureaucracies and makes them powerful in

\footnotetext{
We are grateful to John Boli, Raymond Duvall, Ernst Haas, Peter Haas, Robert Keohane, Keith Krause, Jeffrey Legro, John Malley, Craig Murphy, M. J. Peterson, Mark Pollack, Andrew Moravcsik, Thomas Risse, Duncan Snidal, Steve Weber, Thomas Weiss, and two anonymous referees for their comments. We are especially grateful for the careful attention of the editors of International Organization. Earlier versions of this article were presented at the 1997 APSA meeting, the 1997 ISA meeting, and at various fora. We also acknowledge financial assistance from the Smith Richardson Foundation and the United States Institute of Peace.
} 
modern life can also make them unresponsive to their environments, obsessed with their own rules at the expense of primary missions, and ultimately lead to inefficient, self-defeating behavior. We are not the first to suggest that IOs are more than the reflection of state preferences and that they can be autonomous and powerful actors in global politics. ${ }^{1}$ Nor are we the first to note that IOs, like all organizations, can be dysfunctional and inefficient. ${ }^{2}$ However, our emphasis on the way that characteristics of bureaucracy as a generic cultural form shape IO behavior provides a different and very broad basis for thinking about how IOs influence world politics. ${ }^{3}$

Developing an alternative approach to thinking about IOs is only worthwhile if it produces significant insights and new opportunities for research on major debates in the field. Our approach allows us to weigh in with new perspectives on at least three such debates. First, it offers a different view of the power of IOs and whether or how they matter in world politics. This issue has been at the core of the neoliberalinstitutionalists' debate with neorealists for years. ${ }^{4}$ We show in this article how neoliberal-institutionalists actually disadvantage themselves in their argument with realists by looking at only one facet of IO power. Global organizations do more than just facilitate cooperation by helping states to overcome market failures, collective action dilemmas, and problems associated with interdependent social choice. They also create actors, specify responsibilities and authority among them, and define the work these actors should do, giving it meaning and normative value. Even when they lack material resources, IOs exercise power as they constitute and construct the social world. ${ }^{5}$

Second and related, our perspective provides a theoretical basis for treating IOs as autonomous actors in world politics and thus presents a challenge to the statist ontology prevailing in international relations theories. Despite all their attention to international institutions, one result of the theoretical orientation of neoliberal institutionalists and regimes theorists is that they treat IOs the way pluralists treat the state. IOs are mechanisms through which others (usually states) act; they are not purposive actors. The regimes literature is particularly clear on this point. Regimes are "principles, norms, rules, and decision-making procedures;" they are not actors. ${ }^{6}$ Weber's insights about the normative power of the rational-legal authority that bureaucracies embody and its implications for the ways bureaucracies produce and control social knowledge provide a basis for challenging this view and treating IOs as agents, not just as structure.

1. For Gramscian approaches, see Cox 1980,1992, and 1996; and Murphy 1995. For Society of States approaches, see Hurrell and Woods 1995. For the epistemic communities literature, see Haas 1992. For IO decision-making literature, see Cox et al. 1974; Cox and Jacobson 1977; Cox 1996; and Ness and Brechin 1988. For a rational choice perspective, see Snidal 1996.

2. Haas 1990.

3. Because the neorealist and neoliberal arguments we engage have focused on intergovernmental organizations rather than nongovernmental ones, and because Weberian arguments from which we draw deal primarily with public bureaucracy, we too focus on intergovernmental organizations in this article and use the term international organizations in that way.

4. Baldwin 1993.

5. See Finnemore 1993 and 1996b; and McNeely 1995.

6. Krasner 1983b. 
Third, our perspective offers a different vantage point from which to assess the desirability of IOs. While realists and some policymakers have taken up this issue, surprisingly few other students of IOs have been critical of their performance or desirability. ${ }^{7}$ Part of this optimism stems from central tenets of classical liberalism, which has long viewed IOs as a peaceful way to manage rapid technological change and globalization, far preferable to the obvious alternative-war. ${ }^{8}$ Also contributing to this uncritical stance is the normative judgment about IOs that is built into the theoretical assumptions of most neoliberal and regimes scholars and the economic organization theories on which they draw. IOs exist, in this view, only because they are Pareto improving and solve problems for states. Consequently, if an IO exists, it must be because it is more useful than other alternatives since, by theoretical axiom, states will pull the plug on any IO that does not perform. We find this assumption unsatisfying. IOs often produce undesirable and even self-defeating outcomes repeatedly, without punishment much less dismantlement, and we, as theorists, want to understand why. International relations scholars are familiar with principal-agent problems and the ways in which bureaucratic politics can compromise organizational effectiveness, but these approaches have rarely been applied to IOs. Further, these approaches by no means exhaust sources of dysfunction. We examine one such source that flows from the same rational-legal characteristics that make IOs authoritative and powerful. Drawing from research in sociology and anthropology, we show how the very features that make bureaucracies powerful can also be their weakness.

The claims we make in this article flow from an analysis of the "social stuff" of which bureaucracy is made. We are asking a standard constructivist question about what makes the world hang together or, as Alexander Wendt puts it, "how are things in the world put together so that they have the properties they do." 9 In this sense, our explanation of IO behavior is constitutive and differs from most other international relations approaches. This approach does not make our explanation "mere description," since understanding the constitution of things does essential work in explaining how those things behave and what causes outcomes. Just as understanding how the double-helix DNA molecule is constituted materially makes possible causal arguments about genetics, disease, and other biological processes, so understanding how bureaucracies are constituted socially allows us to hypothesize about the behavior of IOs and the effects this social form might have in world politics. This type of constitutive explanation does not allow us to offer law-like statements such as "if $X$ happens, then $Y$ must follow." Rather, by providing a more complete understanding of what bureaucracy is, we can provide explanations of how certain kinds of bureaucratic behavior are possible, or even probable, and why. ${ }^{10}$

We begin by examining the assumptions underlying different branches of organization theory and exploring their implications for the study of IOs. We argue that assumptions drawn from economics that undergird neoliberal and neorealist treat-

7. See Mearsheimer 1994; and Helms 1996.

8. See Commission on Global Governance 1995; Jacobson 1979, 1; and Doyle 1997.

9. See Ruggie 1998; and Wendt 1998.

10. Wendt 1998. 
ments of IOs do not always reflect the empirical situation of most IOs commonly studied by political scientists. Further, they provide research hypotheses about only some aspects of IOs (like why they are created) and not others (like what they do). We then introduce sociological arguments that help remedy these problems.

In the second section we develop a constructivist approach from these sociological arguments to examine the power wielded by IOs and the sources of their influence. Liberal and realist theories only make predictions about, and consequently only look for, a very limited range of welfare-improving effects caused by IOs. Sociological theories, however, expect and explain a much broader range of impacts organizations can have and specifically highlight their role in constructing actors, interests, and social purpose. We provide illustrations from the UN system to show how IOs do, in fact, have such powerful effects in contemporary world politics. In the third section we explore the dysfunctional behavior of IOs, which we define as behavior that undermines the stated goals of the organization. International relations theorists are familiar with several types of theories that might explain such behavior. Some locate the source of dysfunction in material factors, others focus on cultural factors. Some theories locate the source of dysfunction outside the organization, others locate it inside. We construct a typology, mapping these theories according to the source of dysfunction they emphasize, and show that the same internally generated cultural forces that give IOs their power and autonomy can also be a source of dysfunctional behavior. We use the term pathologies to describe such instances when IO dysfunction can be traced to bureaucratic culture. We conclude by discussing how our perspective helps to widen the research agenda for IOs.

\section{Theoretical Approaches to Organizations}

Within social science there are two broad strands of theorizing about organizations. One is economistic and rooted in assumptions of instrumental rationality and efficiency concerns; the other is sociological and focused on issues of legitimacy and power. ${ }^{11}$ The different assumptions embedded within each type of theory focus attention on different kinds of questions about organizations and provide insights on different kinds of problems.

The economistic approach comes, not surprisingly, out of economics departments and business schools for whom the fundamental theoretical problem, laid out first by Ronald Coase and more recently by Oliver Williamson, is why we have business firms. Within standard microeconomic logic, it should be much more efficient to conduct all transactions through markets rather than "hierarchies" or organizations. Consequently, the fact that economic life is dominated by huge organizations (business firms) is an anomaly. The body of theory developed to explain the existence and power of firms focuses on organizations as efficient solutions to contracting problems, incomplete information, and other market imperfections. ${ }^{12}$ 
This body of organization theory informs neoliberal and neorealist debates over international institutions. Following Kenneth Waltz, neoliberals and neorealists understand world politics to be analogous to a market filled with utility-maximizing competitors. ${ }^{13}$ Thus, like the economists, they see organizations as welfare-improving solutions to problems of incomplete information and high transaction costs. ${ }^{14}$ Neoliberals and realists disagree about the degree to which constraints of anarchy, an interest in relative versus absolute gains, and fears of cheating will scuttle international institutional arrangements or hobble their effectiveness, but both agree, implicitly or explicitly, that IOs help states further their interests where they are allowed to work. ${ }^{15}$ State power may be exercised in political battles inside IOs over where, on the Pareto frontier, political bargains fall, but the notion that IOs are instruments created to serve state interests is not much questioned by neorealist or neoliberal scholars. ${ }^{16}$ After all, why else would states set up these organizations and continue to support them if they did not serve state interests?

Approaches from sociology provide one set of answers to this question. They provide reasons why, in fact, organizations that are not efficient or effective servants of member interests might exist. In so doing, they lead us to look for kinds of power and sources of autonomy in organizations that economists overlook. Different approaches within sociology treat organizations in different ways, but as a group they stand in sharp contrast to the economists' approaches in at least two important respects: they offer a different conception of the relationship between organizations and their environments, and they provide a basis for understanding organizational autonomy.

IOs and their environment. The environment assumed by economic approaches to organizations is socially very thin and devoid of social rules, cultural content, or even other actors beyond those constructing the organization. Competition, exchange, and consequent pressures for efficiency are the dominant environmental characteristics driving the formation and behavior of organizations. Sociologists, by contrast, study organizations in a wider world of nonmarket situations, and, consequently, they begin with no such assumptions. Organizations are treated as "social facts" to be investigated; whether they do what they claim or do it efficiently is an empirical question, not a theoretical assumption of these approaches. Organizations respond not only to other actors pursuing material interests in the environment but also to normative and cultural forces that shape how organizations see the world and conceptualize their own missions. Environments can "select" or favor organizations for reasons other than efficient or responsive behavior. For example, organizations may be created and supported for reasons of legitimacy and normative fit rather than efficient output; they may be created not for what they do but for what they are-for what they represent symbolically and the values they embody. ${ }^{17}$

13. Waltz 1979 .

14. See Vaubel 1991, 27; and Dillon, Ilgen, and Willett 1991.

15. Baldwin 1993.

16. Krasner 1991.

17. See DiMaggio and Powell 1983; Scott 1992; Meyer and Scott 1992, 1-5; Powell and DiMaggio 1991; Weber 1994; and Finnemore 1996a. 
Empirically, organizational environments can take many forms. Some organizations exist in competitive environments that create strong pressures for efficient or responsive behavior, but many do not. Some organizations operate with clear criteria for "success" (like firms that have balance sheets), whereas others (like political science departments) operate with much vaguer missions, with few clear criteria for success or failure and no serious threat of elimination. Our point is simply that when we choose a theoretical framework, we should choose one whose assumptions approximate the empirical conditions of the IO we are analyzing, and that we should be aware of the biases created by those assumptions. Economistic approaches make certain assumptions about the environment in which IOs are embedded that drive researchers who use them to look for certain kinds of effects and not others. Specifying different or more varied environments for IOs would lead us to look for different and more varied effects in world politics. ${ }^{18}$

IO autonomy. Following economistic logic, regime theory and the broad range of scholars working within it generally treat IOs as creations of states designed to further state interests. ${ }^{19}$ Analysis of subsequent IO behavior focuses on processes of aggregating member state preferences through strategic interaction within the structure of the IO. IOs, then, are simply epiphenomena of state interaction; they are, to quote Waltz's definition of reductionism, "understood by knowing the attributes and the interactions of [their] parts." 20

These theories thus treat IOs as empty shells or impersonal policy machinery to be manipulated by other actors. Political bargains shape the machinery at its creation, states may politick hard within the machinery in pursuit of their policy goals, and the machinery's norms and rules may constrain what states can do, but the machinery itself is passive. IOs are not purposive political actors in their own right and have no ontological independence. To the extent that IOs do, in fact, take on a life of their own, they breach the "limits of realism" as well as of neoliberalism by violating the ontological structures of these theories. ${ }^{21}$

The regimes concept spawned a huge literature on interstate cooperation that is remarkably consistent in its treatment of IOs as structure rather than agents. Much of the neoliberal institutionalist literature has been devoted to exploring the ways in which regimes (and IOs) can act as intervening variables, mediating between states' pursuit of self-interest and political outcomes by changing the structure of opportunities and constraints facing states through their control over information, in particular. ${ }^{22}$ Although this line of scholarship accords IOs some causal status (since they demonstrably change outcomes), it does not grant them autonomy and purpose inde-

18. Researchers applying these economistic approaches have become increasingly aware of the mismatch between the assumptions of their models and the empirics of IOs. See Snidal 1996.

19. Note that empirically this is not the case; most IOs now are created by other IOs. See Shanks, Jacobson, and Kaplan 1996.

20. Waltz 1979, 18.

21. Krasner 1983a, 355-68; but see Finnemore 1996b; and Rittberger 1993.

22. See Keohane 1984; and Baldwin 1993. 
pendent of the states that comprise them. Another branch of liberalism has recently divorced itself from the statist ontology and focuses instead on the preferences of social groups as the causal engine of world politics, but, again, this view simply argues for attention to a different group of agents involved in the construction of IOs and competing for access to IO mechanisms. It does not offer a fundamentally different conception of IOs. ${ }^{23}$

The relevant question to ask about this conceptualization is whether it is a reasonable approximation of the empirical condition of most IOs. Our reading of detailed empirical case studies of IO activity suggests not. Yes, IOs are constrained by states, but the notion that they are passive mechanisms with no independent agendas of their own is not borne out by any detailed empirical study of an IO that we have found. Field studies of the European Union provide evidence of independent roles for "eurocrats." 24 Studies of the World Bank consistently identify an independent culture and agendas for action. ${ }^{25}$ Studies of recent UN peacekeeping and reconstruction efforts similarly document a UN agenda that frequently leads to conflict with member states. ${ }^{26}$ Accounts of the UN High Commission on Refugees (UNHCR) routinely note how its autonomy and authority has grown over the years. Not only are IOs independent actors with their own agendas, but they may embody multiple agendas and contain multiple sources of agency - a problem we take up later.

Principal-agent analysis, which has been increasingly employed by students of international relations to examine organizational dynamics, could potentially provide a sophisticated approach to understanding IO autonomy. ${ }^{27}$ Building on theories of rational choice and of representation, these analysts understand IOs as "agents" of states ("principals"). The analysis is concerned with whether agents are responsible delegates of their principals, whether agents smuggle in and pursue their own preferences, and how principals can construct various mechanisms to keep their agents honest. ${ }^{28}$ This framework provides a means of treating IOs as actors in their own right with independent interests and capabilities. Autonomous action by IOs is to be expected in this perspective. It would also explain a number of the nonresponsive and pathological behaviors that concern us because we know that monitoring and shirking problems are pervasive in these principal-agent relationships and that these relationships can often get stuck at suboptimal equilibria.

The problem with applying principal-agent analysis to the study of IOs is that it requires a priori theoretical specification of what IOs want. Principal-agent dynamics are fueled by the disjuncture between what agents want and what principals want. To produce any insights, those two sets of interests cannot be identical. In economics this type of analysis is usually applied to preexisting agents and principals (clients

23. Moravcsik 1997.

24. See Pollack 1997; Ross 1995; and Zabusky 1995; but see Moravcsik 1999.

25. See Ascher 1983; Ayres 1983; Ferguson 1990; Escobar 1995; Wade 1996; Nelson 1995; and Finnemore 1996a.

26. Joint Evaluation of Emergency Assistance to Rwanda 1996.

27. See Pollack 1997; Lake 1996; Vaubel 1991; and Dillon, Ilgen, and Willett 1991.

28. See Pratt and Zeckhauser 1985; and Kiewit and McCubbins 1991. 
hiring lawyers, patients visiting doctors) whose ongoing independentexistence makes specification of independent interests relatively straightforward. The lawyer or the doctor would probably be in business even if you and I did not take our problems to them. IOs, on the other hand, are often created by the principals (states) and given mission statements written by the principals. How, then, can we impute independent preferences a priori?

Scholars of American politics have made some progress in producing substantive theoretical propositions about what U.S. bureaucratic agencies want. Beginning with the pioneering work of William Niskanen, scholars theorized that bureaucracies had interests defined by the absolute or relative size of their budget and the expansion or protection of their turf. At first these interests were imputed, and later they became more closely investigated, substantiated, and in some cases modified or rejected altogether. $^{29}$

Realism and liberalism, however, provide no basis for asserting independent utility functions for IOs. Ontologically, these are theories about states. They provide no basis for imputing interests to IOs beyond the goals states (that is, principals) give them. Simply adopting the rather battered Niskanen hypothesis seems less than promising given the glaring anomalies-for example, the opposition of many NATO and OSCE (Organization for Security and Cooperation in Europe) bureaucrats to those organizations' recent expansion and institutionalization. There are good reasons to assume that organizations care about their resource base and turf, but there is no reason to presume that such matters exhaust or even dominate their interests. Indeed, ethnographic studies of IOs describe a world in which organizational goals are strongly shaped by norms of the profession that dominate the bureaucracy and in which interests themselves are varied, often in flux, debated, and worked out through interactions between the staff of the bureaucracy and the world in which they are embedded. ${ }^{30}$

Various strands of sociological theory can help us investigate the goals and behavior of IOs by offering a very different analytical orientation than the one used by economists. Beginning with Weber, sociologists have explored the notion that bureaucracy is a peculiarly modern cultural form that embodies certain values and can have its own distinct agenda and behavioral dispositions. Rather than treating organizations as mere arenas or mechanisms through which other actors pursue interests, many sociological approaches explore the social content of the organization-its culture, its legitimacy concerns, dominant norms that govern behavior and shape interests, and the relationship of these to a larger normative and cultural environment. Rather than assuming behavior that corresponds to efficiency criteria alone, these approaches recognize that organizations also are bound up with power and social control in ways that can eclipse efficiency concerns.

29. See Niskanen 1971; Miller and Moe 1983; Weingast and Moran 1983; Moe 1984; and Sigelman 1986.

30. See Ascher 1983; Zabusky 1995; Barnett 1997b; and Wade 1996. 


\section{The Power of IOs}

IOs can become autonomous sites of authority, independent from the state "principals" who may have created them, because of power flowing from at least two sources: (1) the legitimacy of the rational-legal authority they embody, and (2) control over technical expertise and information. The first of these is almost entirely neglected by the political science literature, and the second, we argue, has been conceived of very narrowly, leading scholars to overlook some of the most basic and consequential forms of IO influence. Taken together, these two features provide a theoretical basis for treating IOs as autonomous actors in contemporary world politics by identifying sources of support for them, independent of states, in the larger social environment. Since rational-legal authority and control over expertise are part of what defines and constitutes any bureaucracy (a bureaucracy would not be a bureaucracy without them), the autonomy that flows from them is best understood as a constitutive effect, an effect of the way bureaucracy is constituted, which, in turn, makes possible (and in that sense causes) other processes and effects in global politics.

\section{Sources of IO Autonomy and Authority}

To understand how IOs can become autonomous sites of authority we turn to Weber and his classic study of bureaucratization. Weber was deeply ambivalent about the increasingly bureaucratic world in which he lived and was well-attuned to the vices as well as the virtues of this new social form of authority. ${ }^{31}$ Bureaucracies are rightly considered a grand achievement, he thought. They provide a framework for social interaction that can respond to the increasingly technical demands of modern life in a stable, predictable, and nonviolent way; they exemplify rationality and are technically superior to previous forms of rule because they bring precision, knowledge, and continuity to increasingly complex social tasks. ${ }^{32}$ But such technical and rational achievements, according to Weber, come at a steep price. Bureaucracies are political creatures that can be autonomous from their creators and can come to dominate the societies they were created to serve, because of both the normative appeal of rationallegal authority in modern life and the bureaucracy's control over technical expertise and information. We consider each in turn.

Bureaucracies embody a form of authority, rational-legal authority, that modernity views as particularly legitimate and good. In contrast to earlier forms of authority that were invested in a leader, legitimate modern authority is invested in legalities, procedures, and rules and thus rendered impersonal. This authority is "rational" in that it deploys socially recognized relevant knowledge to create rules that determine how goals will be pursued. The very fact that they embody rationality is what makes bureaucracies powerful and makes people willing to submit to this kind of authority.

31. See Weber 1978, 196-97; Weber 1947; Mouzelis 1967; and Beetham 1985 and 1996.

32. See Schaar 1984, 120; Weber 1978, 973; and Beetham 1985, 69. 


\section{According to Weber,}

in legal authority, submission does not rest upon the belief and devotion to charismatically gifted persons. . . or upon piety toward a personal lord and master who is defined by an ordered tradition.... Rather submission under legal authority is based upon an impersonal bond to the generally defined and functional "duty of office." The official duty-like the corresponding right to exercise authority: the "jurisdictional competency"—is fixed by rationally established norms, by enactments, decrees, and regulations in such a manner that the legitimacy of the authority becomes the legality of the general rule, which is purposely thought out, enacted, and announced with formal correctness. ${ }^{33}$

When bureaucrats do something contrary to your interests or that you do not like, they defend themselves by saying "Sorry, those are the rules" or "just doing my job." "The rules" and "the job" are the source of great power in modern society. It is because bureaucrats in IOs are performing "duties of office" and implementing "rationally established norms" that they are powerful.

A second basis of autonomy and authority, intimately connected to the first, is bureaucratic control over information and expertise. A bureaucracy's autonomy derives from specialized technical knowledge, training, and experience that is not immediately available to other actors. While such knowledge might help the bureaucracy carry out the directives of politicians more efficiently, Weber stressed that it also gives bureaucracies power over politicians (and other actors). It invites and at times requires bureaucracies to shape policy, not just implement it. ${ }^{34}$

The irony in both of these features of authority is that they make bureaucracies powerful precisely by creating the appearance of depoliticization. The power of IOs, and bureaucracies generally, is that they present themselves as impersonal, technocratic, and neutral — as not exercising power but instead as serving others; the presentation and acceptance of these claims is critical to their legitimacy and authority. ${ }^{35}$ Weber, however, saw through these claims. According to him, the depoliticized character of bureaucracy that legitimates it could be a myth: "Behind the functional purposes [of bureaucracy], of course, 'ideas of culture-values' usually stand." $36 \mathrm{Bu}$ reaucracies always serve some social purpose or set of cultural values. That purpose may be normatively "good," as Weber believed the Prussian nationalism around him was, but there was no a priori reason to assume this.

In addition to embodying cultural values from the larger environment that might be desirable or not, bureaucracies also carry with them behavioral dispositions and values flowing from the rationality that legitimates them as a cultural form. Some of these, like the celebration of knowledge and expertise, Weber admired. Others concerned him greatly, and his descriptions of bureaucracy as an "iron cage" and bureaucrats as "specialists without spirit" are hardly an endorsement of the bureaucratic

33. Gerth and Mills 1978, 299 (italics in original).

34. See Gerth and Mills 1978, 233; Beetham 1985, 74-75; and Schaar 1984, 120.

35. We thank John Boli for this insight. Also see Fisher 1997; Ferguson 1990; Shore and Wright 1997; and Burley and Mattli 1993.

36. Gerth and Mills 1978, 199. 
form. ${ }^{37}$ Bureaucracy can undermine personal freedom in important ways. The very impersonal, rule-bound character that empowers bureaucracy also dehumanizes it. Bureaucracies often exercise their power in repressive ways, in the name of general rules because rules are their raison d'être. This tendency is exacerbated by the way bureaucracies select and reward narrowed professionals seeking secure careers internally_people who are "lacking in heroism, human spontaneity, and inventiveness." 38 Following Weber, we investigate rather than assume the "goodness" of bureaucracy.

Weber's insights provide a powerful critique of the ways in which international relations scholars have treated IOs. The legitimacy of rational-legal authority suggests that IOs may have an authority independent of the policies and interests of states that create them, a possibility obscured by the technical and apolitical treatment of IOs by both realists and neoliberals. Nor have realists and neoliberals considered how control over information hands IOs a basis of autonomy. Susan Strange, at the forefront among realists in claiming that information is power, has emphatically stated that IOs are simply the agents of states. Neoliberals have tended to treat information in a highly technocratic and depoliticized way, failing to see how information is power. ${ }^{39}$ As IOs create transparencies and level information asymmetries among states (a common policy prescription of neoliberals) they create new information asymmetries between IOs and states. Given the neoliberal assumption that IOs have no goals independent of states, such asymmetries are unimportant; but if IOs have autonomous values and behavioral predispositions, then such asymmetries may be highly consequential.

Examples of the ways in which IOs have become autonomous because of their embodiment of technical rationality and control over information are not hard to find. The UN's peacekeepers derive part of their authority from the claim that they are independent, objective, neutral actors who simply implement Security Council resolutions. UN officials routinely use this language to describe their role and are explicit that they understand this to be the basis of their influence. As a consequence, UN officials spend considerable time and energy attempting to maintain the image that they are not the instrument of any great power and must be seen as representatives of "the international community" as embodied in the rules and resolutions of the UN. ${ }^{40}$ The World Bank is widely recognized to have exercised power over development policies far greater than its budget, as a percentage of North/South aid flows, would suggest because of the expertise it houses. While competing sites of expertise in development have proliferated in recent years, for decades after its founding the World Bank was a magnet for the "best and brightest" among "development experts." Its staff had and continues to have impressive credentials from the most pres-

37. See Weber [1930] 1978, 181-83; and Clegg 1994a, 152-55.

38. Gerth and Mills 1978, 216, 50, 299. For the extreme manifestation of this bureaucratic characteristic, see Arendt 1977.

39. See Strange 1997; and Keohane 1984.

40. See David Rieff, "The Institution that Saw No Evil," The New Republic, 12 February 1996, 19-24; and Barnett 1997b. 
tigious universities and the elaborate models, reports, and research groups it has sponsored over the years were widely influential among the "development experts" in the field. This expertise, coupled with its claim to "neutrality" and its "apolitical" technocratic decision-making style, have given the World Bank an authoritative voice with which it has successfully dictated the content, direction, and scope of global development over the past fifty years. ${ }^{41}$ Similarly, official standing and long experience with relief efforts have endowed the UNHCR with "expert" status and consequent authority in refugee matters. This expertise, coupled with its role in implementing international refugee conventions and law ("the rules" regarding refugees), has allowed the UNHCR to make life and death decisions about refugees without consulting the refugees, themselves, and to compromise the authority of states in various ways in setting up refugee camps. ${ }^{42}$ Note that, as these examples show, technical knowledge and expertise need not be "scientific" in nature to create autonomy and power for IOs.

\section{The Power of IOs}

If IOs have autonomy and authority in the world, what do they do with it? A growing body of research in sociology and anthropology has examined ways in which IOs exercise power by virtue of their culturally constructed status as sites of authority; we distill from this research three broad types of IO power. We examine how IOs (1) classify the world, creating categories of actors and action; (2) fix meanings in the social world; and (3) articulate and diffuse new norms, principles, and actors around the globe. All of these sources of power flow from the ability of IOs to structure knowledge. ${ }^{43}$

Classification. An elementary feature of bureaucracies is that they classify and organize information and knowledge. This classification process is bound up with power. "Bureaucracies," writes Don Handelman, "are ways of making, ordering, and knowing social worlds." They do this by "moving persons among social categories or by inventing and applying such categories." 44 The ability to classify objects, to shift their very definition and identity, is one of bureaucracy's greatest sources of power. This power is frequently treated by the objects of that power as accomplished through caprice and without regard to their circumstances but is legitimated and justified by bureaucrats with reference to the rules and regulations of the bureaucracy. Consequences of this bureaucratic exercise of power may be identity defining, or even life threatening.

Consider the evolving definition of "refugee." The category "refugee" is not at all straightforward and must be distinguished from other categories of individuals who

41. See Wade 1996; Ayres 1983; Ascher 1983; Finnemore 1996b; and Nelson 1995.

42. See Malkki 1996; Hartigan 1992; and Harrell-Bond 1989.

43. See Foucault 1977, 27; and Clegg 1994b, 156-59. International relations theory typically disregards the negative side of the knowledge and power equation. For an example, see Haas 1992.

44. Handelman 1995, 280. See also Starr 1992; and Wright 1994, 22. 
are "temporarily" and "involuntarily" living outside their country of origindisplaced persons, exiles, economic migrants, guest workers, diaspora communities, and those seeking political asylum. The debate over the meaning of "refugee" has been waged in and around the UNHCR. The UNHCR's legal and operational definition of the category strongly influences decisions about who is a refugee and shapes UNHCR staff decisions in the field-decisions that have a tremendous effect on the life circumstance of thousands of people. ${ }^{45}$ These categories are not only political and legal but also discursive, shaping a view among UNHCR officials that refugees must, by definition, be powerless, and that as powerless actors they do not have to be consulted in decisions such as asylum and repatriation that will directly and dramatically affect them. ${ }^{46}$ Guy Gran similarly describes how the World Bank sets up criteria to define someone as a peasant in order to distinguish them from a farmer, day laborer, and other categories. The classification matters because only certain classes of people are recognized by the World Bank's development machinery as having knowledge that is relevant in solving development problems. ${ }^{47}$ Categorization and classification are a ubiquitous feature of bureaucratization that has potentially important implications for those being classified. To classify is to engage in an act of power.

The fixing of meanings. IOs exercise power by virtue of their ability to fix meanings, which is related to classification. ${ }^{48}$ Naming or labeling the social context establishes the parameters, the very boundaries, of acceptable action. Because actors are oriented toward objects and objectives on the basis of the meaning that they have for them, being able to invest situations with a particular meaning constitutes an important source of power. ${ }^{49}$ IOs do not act alone in this regard, but their organizational resources contribute mightily to this end.

There is strong evidence of this power from development studies. Arturo Escobar explores how the institutionalization of the concept of "development" after World War II spawned a huge international apparatus and how this apparatus has now spread its tentacles in domestic and international politics through the discourse of development. The discourse of development, created and arbitrated in large part by IOs, determines not only what constitutes the activity (what development is) but also who (or what) is considered powerful and privileged, that is, who gets to do the developing (usually the state or IOs) and who is the object of development (local groups). ${ }^{50}$

Similarly, the end of the Cold War encouraged a reexamination of the definition of security. ${ }^{51}$ IOs have been at the forefront of this debate, arguing that security pertains not only to states but also to individuals and that the threats to security may be

45. See Weiss and Pasic 1997; Goodwin-Gill 1996; and Anonymous 1997.

46. See Harrell-Bond 1989; Walkup 1997; and Malkki 1996.

47. Gran 1986.

48. See Williams 1996; Clegg 1994b; Bourdieu 1994; Carr [1939] 1964; and Keeley 1990.

49. Blumer 1969.

50. See Gupta 1998; Escobar 1995; Cooper and Packard 1998; Gran 1986; Ferguson 1990; and Wade 1996.

51. See Matthews 1989; and Krause and Williams 1996. 
economic, environmental, and political as well as military..$^{52}$ In forwarding these alternative definitions of security, officials from various IOs are empowering a different set of actors and legitimating an alternative set of practices. Specifically, when security meant safety from invading national armies, it privileged state officials and invested power in military establishments. These alternative definitions of security shift attention away from states and toward the individuals who are frequently threatened by their own government, away from military practices and toward other features of social life that might represent a more immediate and daily danger to the lives of individuals.

One consequence of these redefined meanings of development and security is that they legitimate, and even require, increased levels of IO intervention in the domestic affairs of states-particularly Third World states. This is fairly obvious in the realm of development. The World Bank, the International Monetary Fund (IMF), and other development institutions have established a web of interventions that affect nearly every phase of the economy and polity in many Third World states. As "rural development," "basic human needs," and "structural adjustment" became incorporated into the meaning of development, IOs were permitted, even required, to become intimately involved in the domestic workings of developing polities by posting inhouse "advisors" to run monetary policy, reorganizing the political economy of entire rural regions, regulating family and reproductive practices, and mediating between governments and their citizens in a variety of ways. ${ }^{53}$

The consequences of redefining security may be similar. Democratization, human rights, and the environment have all now become tied to international peace and security, and IOs justify their interventions in member states on these grounds, particularly in developing states. For example, during the anti-apartheid struggle in South Africa, human rights abuses came to be classified as security threats by the UN Security Council and provided grounds for UN involvement there. Now, that linkage between human rights and security has become a staple of the post-Cold War environment. Widespread human rights abuses anywhere are now cause for UN intervention, and, conversely, the UN cannot carry out peacekeeping missions without promoting human rights. ${ }^{54}$ Similarly, environmental disasters in Eastern Europe and the newly independent states of the former Soviet Union and water rights allocations in the Middle East have also come to be discussed under the rubric of "environmental security" and are thus grounds for IO intervention. The United Nations Development Program argues that there is an important link between human security and sustainable development and implicitly argues for greater intervention in the management of environment as a means to promote human security. ${ }^{55}$

Diffusion of norms. Having established rules and norms, IOs are eager to spread the benefits of their expertise and often act as conveyor belts for the transmission of

52. See UN Development Program 1994; and Boutros-Ghali 1995.

53. See Escobar 1995; Ferguson 1990; and Feldstein 1998.

54. World Conference on Human Rights 1993.

55. UN Development Program 1994. 
norms and models of "good" political behavior. ${ }^{56}$ There is nothing accidental or unintended about this role. Officials in IOs often insist that part of their mission is to spread, inculcate, and enforce global values and norms. They are the "missionaries" of our time. Armed with a notion of progress, an idea of how to create the better life, and some understanding of the conversion process, many IO elites have as their stated purpose a desire to shape state practices by establishing, articulating, and transmitting norms that define what constitutes acceptable and legitimate state behavior. To be sure, their success depends on more than their persuasive capacities, for their rhetoric must be supported by power, sometimes (but not always) state power. But to overlook how state power and organizational missionaries work in tandem and the ways in which IO officials channel and shape states' exercise of power is to disregard a fundamental feature of value diffusion. ${ }^{57}$

Consider decolonization as an example. The UN Charter announced an intent to universalize sovereignty as a constitutive principle of the society of states at a time when over half the globe was under some kind of colonial rule; it also established an institutional apparatus to achieve that end (most prominently the Trusteeship Council and the Special Committee on Colonialism). These actions had several consequences. One was to eliminate certain categories of acceptable action for powerful states. Those states that attempted to retain their colonial privileges were increasingly viewed as illegitimate by other states. Another consequence was to empower international bureaucrats (at the Trusteeship Council) to set norms and standards for "stateness." Finally, the UN helped to ensure that throughout decolonization the sovereignty of these new states was coupled with territorial inviolability. Colonial boundaries often divided ethnic and tribal groups, and the UN was quite concerned that in the process of "self-determination," these governments containing "multiple" or "partial" selves might attempt to create a whole personality through territorial adjustment - a fear shared by many of these newly decolonized states. The UN encouraged the acceptance of the norm of sovereignty-as-territorial-integrity through resolutions, monitoring devices, commissions, and one famous peacekeeping episode in Congo in the 1960s. ${ }^{58}$

Note that, as with other IO powers, norm diffusion, too, has an expansionary dynamic. Developing states continue to be popular targets for norm diffusion by IOs, even after they are independent. The UN and the European Union are now actively involved in police training in non-Western states because they believe Western policing practices will be more conducive to democratization processes and the establishment of civil society. But having a professional police establishment assumes that there is a professional judiciary and penal system where criminals can be tried and jailed; and a professional judiciary, in turn, presupposes that there are lawyers that can come before the court. Trained lawyers presuppose a code of law. The result is a package of reforms sponsored by IOs aimed at transforming non-Western societies

56. See Katzenstein 1996; Finnemore 1996b; and Legro 1997.

57. See Alger 1963, 425; and Claude 1966, 373.

58. See McNeely 1995; and Jackson 1993. 
into Western societies. ${ }^{59}$ Again, while Western states are involved in these activities and therefore their values and interests are part of the reasons for this process, international bureaucrats involved in these activities may not see themselves as doing the bidding for these states but rather as expressing the interests and values of the bureaucracy.

Other examples of this kind of norm diffusion are not hard to find. The IMF and the World Bank are explicit about their role as transmitters of norms and principles from advanced market economies to less-developed economies. ${ }^{60}$ The IMF's Articles of Agreement specifically assign it this task of incorporating less-developed economies into the world economy, which turns out to mean teaching them how to "be" market economies. The World Bank, similarly, has a major role in arbitrating the meaning of development and norms of behavior appropriate to the task of developing oneself, as was discussed earlier. The end of the Cold War has opened up a whole new set of states to this kind of norm diffusion task for IOs. According to former Secretary of Defense William Perry, one of the functions of NATO expansion is to inculcate "modern" values and norms into the Eastern European countries and their militaries..$^{61}$ The European Bank for Reconstruction and Development has, as part of its mandate, the job of spreading democracy and private enterprise. The OSCE is striving to create a community based on shared values, among these respect for democracy and human rights. This linkage is also strong at the UN as evident in The Agenda for Democratization and The Agenda for Peace. ${ }^{62}$ Once democratization and human rights are tied to international peace and security, the distinctions between international and domestic governance become effectively erased and IOs have license to intervene almost anywhere in an authoritative and legitimate manner. ${ }^{63}$

Realists and neoliberals may well look at these effects and argue that the classificatory schemes, meanings, and norms associated with IOs are mostly favored by strong states. Consequently, they would argue, the power we attribute to IOs is simply epiphenomenal of state power. This argument is certainly one theoretical possibility, but it is not the only one and must be tested against others. Our concern is that because these theories provide no ontological independence for IOs, they have no way to test for autonomy nor have they any theoretical cause or inclination to test for it since, by theoretical axiom, autonomy cannot exist. The one empirical domain in which the statist view has been explicitly challenged is the European Union, and empirical studies there have hardly produced obvious victory for the "intergovernmentalist" approach.$^{64}$ Recent empirical studies in the areas of human rights, weapons taboos, and environmental practices also cast doubt on the statist approach by providing evidence about the ways in which nongovernmental and intergovernmen-

59. Call and Barnett forthcoming.

60. Wade 1996.

61. See Perry 1996; and Ruggie 1996.

62. Boutros-Ghali 1995 and 1996a,b.

63. Keen and Hendrie, however, suggest that nongovernmental organizations and IOs can be the longterm beneficiaries of intervention. See Keen 1994; and Hendrie 1997.

64. See Burley and Mattli 1993; Pollack 1997; and Sandholtz 1993. 
tal organizations successfully promote policies that are not (or not initially) supported by strong states. ${ }^{65}$ Certainly there are occasions when strong states do drive IO behavior, but there are also times when other forces are at work that eclipse or significantly dampen the effects of states on IOs. Which causal mechanisms produce which effects under which conditions is a set of relationships that can be understood only by intensive empirical study of how these organizations actually do their businessresearch that would trace the origins and evolution of IO policies, the processes by which they are implemented, discrepancies between implementation and policy, and overall effects of these policies.

\section{The Pathologies of IOs}

Bureaucracies are created, propagated, and valued in modern society because of their supposed rationality and effectiveness in carrying out social tasks. These same considerations presumably also apply to IOs. Ironically, though, the folk wisdom about bureaucracies is that they are inefficient and unresponsive. Bureaucracies are infamous for creating and implementing policies that defy rational logic, for acting in ways that are at odds with their stated mission, and for refusing requests of and turning their backs on those to whom they are officially responsible. ${ }^{66}$ Scholars of U.S. bureaucracy have recognized this problem and have devoted considerable energy to understanding a wide range of undesirable and inefficient bureaucratic behaviors caused by bureaucratic capture and slack and to exploring the conditions under which "suboptimal equilibria" may arise in organizational structures. Similarly, scholars researching foreign policy decision making and, more recently, those interested in learning in foreign policy have investigated organizational dynamics that produce self-defeating and inefficient behavior in those contexts. ${ }^{67}$

IOs, too, are prone to dysfunctional behaviors, but international relations scholars have rarely investigated this, in part, we suspect, because the theoretical apparatus they use provides few grounds for expecting undesirable IO behavior. ${ }^{68}$ The statecentric utility-maximizing frameworks most international relations scholars have borrowed from economics simply assume that IOs are reasonably responsive to state interests (or, at least, more responsive than alternatives), otherwise states would withdraw from them. This assumption, however, is a necessary theoretical axiom of these frameworks; it is rarely treated as a hypothesis subject to empirical investigation. ${ }^{69}$ With little theoretical reason to expect suboptimal or self-defeating behavior in IOs, these scholars do not look for it and have had little to say about it. Policymakers, however, have been quicker to perceive and address these problems and are putting

65. See Keck and Sikkink 1998; Wapner 1996; Price 1997; and Thomas forthcoming.

66. March and Olsen 1989, chap. 5.

67. See Nye 1987; Haas 1990; Haas and Haas 1995; and Sagan 1993.

68. Two exceptions are Gallaroti 1991; and Snidal 1996.

69. Snidal 1996. 


\begin{tabular}{c|l|l|}
\multicolumn{1}{c}{} & \multicolumn{1}{c}{ Internal } & \multicolumn{1}{c}{ External } \\
\cline { 2 - 3 } Material & $\begin{array}{l}\text { Bureaucratic } \\
\text { politics }\end{array}$ & $\begin{array}{l}\text { Realism/ } \\
\text { neoliberal } \\
\text { institutionalism }\end{array}$ \\
\cline { 2 - 3 } Cultural & $\begin{array}{l}\text { Bureaucratic } \\
\text { culture }\end{array}$ & $\begin{array}{l}\text { World polity } \\
\text { model }\end{array}$ \\
\hline
\end{tabular}

FIGURE 1. Theories of international organization dysfunction

them on the political agenda. It is time for scholars, too, to begin to explore these issues more fully.

In this section we present several bodies of theorizing that might explain dysfunctional IO behavior, which we define as behavior that undermines the IO's stated objectives. Thus our vantage point for judging dysfunction (and later pathology) is the publicly proclaimed mission of the organization. There may be occasions when overall organizational dysfunction is, in fact, functional for certain members or others involved in the IO's work, but given our analysis of the way claims of efficiency and effectiveness act to legitimate rational-legal authority in our culture, whether organizations actually do what they claim and accomplish their missions is a particularly important issue to examine. Several bodies of theory provide some basis for understanding dysfunctional behavior by IOs, each of which emphasizes a different locus of causality for such behavior. Analyzing these causes, we construct a typology of these explanations that locates them in relation to one another. Then, drawing on the work of James March and Johan Olsen, Paul DiMaggio and Walter Powell, and other sociological institutionalists, we elaborate how the same sources of bureaucratic power, sketched earlier, can cause dysfunctional behavior. We term this particular type of dysfunction pathology. ${ }^{70}$ We identify five features of bureaucracy that might produce pathology, and using examples from the UN system we illustrate the way these might work in IOs.

Extant theories about dysfunction can be categorized in two dimensions: (1) whether they locate the cause of IO dysfunction inside or outside the organization, and (2) whether they trace the causes to material or cultural forces. Mapping theories on these dimensions creates the typology shown in Figure 1.

Within each cell we have identified a representative body of theory familiar to most international relations scholars. Explanations of IO dysfunction that emphasize the pursuit of material interests within an organization typically examine how competition among subunits over material resources leads the organization to make deci-

70. Karl Deutsch used the concept of pathology in a way similar to our usage. We thank Hayward Alker for this point. Deutsch 1963, 170. 
sions and engage in behaviors that are inefficient or undesirable as judged against some ideal policy that would better allow the IO to achieve its stated goals. Bureaucratic politics is the best-known theory here, and though current scholars of international politics have not widely adopted this perspective to explain IO behavior, it is relatively well developed in the older IO literature. ${ }^{71}$ Graham Allison's central argument is that the "name of the game is politics: bargaining along regularized circuits among players positioned hierarchically within the government. Government behavior can thus be understood as . . results of these bargaining games." 72 In this view, decisions are not made after a rational decision process but rather through a competitive bargaining process over turf, budgets, and staff that may benefit parts of the organization at the expense of overall goals.

Another body of literature traces IO dysfunctional behavior to the material forces located outside the organization. Realist and neoliberal theories might posit that state preferences and constraints are responsible for understanding IO dysfunctional behavior. In this view IOs are not to blame for bad outcomes, states are. IOs do not have the luxury of choosing the optimal policy but rather are frequently forced to chose between the bad and the awful because more desirable policies are denied to them by states who do not agree among themselves and/or do not wish to see the IO fulfill its mandate in some particular instance. As Robert Keohane observed, IOs often engage in policies not because they are strong and have autonomy but because they are weak and have none. ${ }^{73}$ The important point of these theories is that they trace IO dysfunctional behavior back to the environmental conditions established by, or the explicit preferences of, states.

Cultural theories also have internal and external variants. We should note that many advocates of cultural theories would reject the claim that an organization can be understood apart from its environment or that culture is separable from the material world. Instead they would stress how the organization is permeated by that environment, defined in both material and cultural terms, in which it is embedded. Many are also quite sensitive to the ways in which resource constraints and the material power of important actors will shape organizational culture. That said, these arguments clearly differ from the previous two types in their emphasis on ideational and cultural factors and clearly differ among themselves in the motors of behavior emphasized. For analytical clarity we divide cultural theories according to whether they see the primary causes of the IO's dysfunctional behavior as deriving from the culture of the organization (internal) or of the environment (external).

The world polity model exemplifies theories that look to external culture to understand an IO's dysfunctional behavior. There are two reasons to expect dysfunctional behavior here. First, because IO practices reflect a search for symbolic legitimacy rather than efficiency, IO behavior might be only remotely connected to the efficient implementation of its goals and more closely coupled to legitimacy criteria that come

71. See Allison 1971; Haas 1990; Cox et al. 1974; and Cox and Jacobson 1977.

72. See Allison 1971, 144; and Bendor and Hammond 1992.

73. Personal communication to the authors. 
from the cultural environment. ${ }^{74}$ For instance, many arms-export control regimes now have a multilateral character not because of any evidence that this architecture is the most efficient way to monitor and prevent arms exports but rather because multilateralism has attained a degree of legitimacy that is not empirically connected to any efficiency criteria. ${ }^{75}$ Second, the world polity is full of contradictions; for instance, a liberal world polity has several defining principles, including market economics and human equality, that might conflict at any one moment. Thus, environments are often ambiguous about missions and contain varied, often conflicting, functional, normative, and legitimacy imperatives. ${ }^{76}$ Because they are embedded in that cultural environment, IOs can mirror and reproduce those contradictions, which, in turn, can lead to contradictory and ultimately dysfunctional behavior.

Finally, organizations frequently develop distinctive internal cultures that can promote dysfunctional behavior, behavior that we call "pathological." The basic logic of this argument flows directly from our previous observations about the nature of bureaucracy as a social form. Bureaucracies are established as rationalized means to accomplish collective goals and to spread particular values. To do this, bureaucracies create social knowledge and develop expertise as they act upon the world (and thus exercise power). But the way bureaucracies are constituted to accomplish these ends can, ironically, create a cultural disposition toward undesirable and ultimately selfdefeating behavior. ${ }^{77}$ Two features of the modern bureaucratic form are particularly important in this regard. The first is the simple fact that bureaucracies are organized around rules, routines, and standard operating procedures designed to trigger a standard and predictable response to environmental stimuli. These rules can be formal or informal, but in either case they tell actors which action is appropriate in response to a specific stimuli, request, or demand. This kind of routinization is, after all, precisely what bureaucracies are supposed to exhibit-it is what makes them effective and competent in performing complex social tasks. However, the presence of such rules also compromises the extent to which means-ends rationality drives organizational behavior. Rules and routines may come to obscure overall missions and larger social goals. They may create "ritualized behavior" in bureaucrats and construct a very parochial normative environment within the organization whose connection to the larger social environment is tenuous at best. ${ }^{78}$

Second, bureaucracies specialize and compartmentalize. They create a division of labor on the logic that because individuals have only so much time, knowledge, and expertise, specialization will allow the organization to emulate a rational decisionmaking process ${ }^{79}$ Again, this is one of the virtues of bureaucracy in that it provides a way of overcoming the limitations of individual rationality and knowledge by embedding those individuals in a structure that takes advantage of their competencies with-

74. See Meyer and Rowan 1977; Meyer and Zucker 1989; Weber 1994; and Finnemore 1996a.

75. Lipson 1999.

76. McNeely 1995.

77. See Vaughan 1996; and Lipartito 1995.

78. See March and Olsen 1989,21-27; and Meyer and Rowan 1977.

79. See March and Olsen 1989, 26-27; and March 1997. 
out having to rely on their weaknesses. However, it, too, has some negative consequences. Just as rules can eclipse goals, concentrated expertise and specialization can (and perhaps must) limit bureaucrats' field of vision and create subcultures within bureaucracy that are distinct from those of the larger environment. Professional training plays a particularly strong role here since this is one widespread way we disseminate specialized knowledge and credential "experts." Such training often gives experts, indeed is designed to give them, a distinctive worldview and normative commitments, which, when concentrated in a subunit of an organization, can have pronounced effects on behavior. ${ }^{80}$

Once in place, an organization's culture, understood as the rules, rituals, and beliefs that are embedded in the organization (and its subunits), has important consequences for the way individuals who inhabit that organization make sense of the world. It provides interpretive frames that individuals use to generate meaning. ${ }^{81}$ This is more than just bounded rationality; in this view, actors' rationality itself, the very means and ends that they value, are shaped by the organizational culture. ${ }^{82}$ Divisions and subunits within the organization may develop their own cognitive frameworks that are consistent with but still distinct from the larger organization, further complicating this process.

All organizations have their own culture (or cultures) that shape their behavior. The effects of bureaucratic culture, however, need not be dysfunctional. Indeed, specific organizational cultures may be valued and actively promoted as a source of "good" behavior, as students of business culture know very well. Organizational culture is tied to "good" and "bad" behavior, alike, and the effects of organizational culture on behavior are an empirical question to be researched.

To further such research, we draw from studies in sociology and anthropology to explore five mechanisms by which bureaucratic culture can breed pathologies in IOs: the irrationality of rationalization, universalism, normalization of deviance, organizational insulation, and cultural contestation. The first three of these mechanisms all flow from defining features of bureaucracy itself. Consequently, we expect them to be present in any bureaucracy to a limited degree. Their severity may be increased, however, by specific empirical conditions of the organization. Vague mission, weak feedback from the environment, and strong professionalism all have the potential to exacerbate these mechanisms and to create two others, organizational insulation and cultural contestation, through processes we describe later. Our claim, therefore, is that the very nature of bureaucracy - the "social stuff" of which it is made - creates behavioral predispositions that make bureaucracy prone to these kinds of behaviors. ${ }^{83}$ But the connection between these mechanisms and pathological behavior is probabilistic, not deterministic, and is consistent with our constitutive analysis. Whether, in fact, mission-defeating behavior occurs depends on empirical condi-

80. See DiMaggio and Powell 1983; and Schien 1996.

81. See Starr 1992, 160; Douglas 1986; and Berger and Luckman 1966, chap. 1.

82. See Campbell 1998, 378; Alvesson 1996; Burrell and Morgan 1979; Dobbin 1994; and Immergut 1998, 14-19.

83. Wendt 1998. 
tions. We identify three such conditions that are particularly important (mission, feedback, and professionals) and discuss how they intensify these inherent predispositions and activate or create additional ones.

Irrationality of rationalization. Weber recognized that the "rationalization" processes at which bureaucracies excelled could be taken to extremes and ultimately become irrational if the rules and procedures that enabled bureaucracies to do their jobs became ends in themselves. Rather than designing the most appropriate and efficient rules and procedures to accomplish their missions, bureaucracies often tailor their missions to fit the existing, well-known, and comfortable rulebook ${ }^{84}$ Thus, means (rules and procedures) may become so embedded and powerful that they determine ends and the way the organization defines its goals. One observer of the World Bank noted how, at an operational level, the bank did not decide on development goals and collect data necessary to pursue them. Rather, it continued to use existing data-collection procedures and formulated goals and development plans from those data alone ${ }^{85} \mathrm{UN}$-mandated elections may be another instance where means become ends in themselves. The "end" pursued in the many troubled states where the UN has been involved in reconstruction is presumably some kind of peaceful, stable, just government. Toward that end, the UN has developed a repertoire of instruments and responses that are largely intended to promote something akin to a democratic government. Among those various repertoires, elections have become privileged as a measure of "success" and a signal of an operation's successful conclusion. Consequently, UN (and other IO) officials have conducted elections even when evidence suggests that such elections are either premature or perhaps even counterproductive (frequently acknowledged as much by state and UN officials). ${ }^{86}$ In places like Bosnia elections have ratified precisely the outcome the UN and outside powers had intervened to prevent — ethnic cleansing — and in places like Africa elections are criticized as exacerbating the very ethnic tensions they were ostensibly designed to quell.

UN peacekeeping might also provide examples. As the UN began to involve itself in various "second-generation operations" that entailed the management and reconciliation of domestic conflicts it turned to the only instrument that was readily available in sufficient numbers - peacekeeping units. Peacekeepers, however, are military troops, trained to handle interstate conflict and to be interposed between two contending national armies, operating with their consent. Some UN staff, state officials, and peacekeeping scholars worried that peacekeepers might be inappropriate for the demands of handling domestic security. They feared that peacekeepers would transfer the skills and attitudes that had been honed for one environment to another without fully considering the adjustments required. According to some observers, peacekeepers did just that: they carried their interstate conflict equipment and mindset into new situations and so created a more aggressive and offensively minded posture than

84. Beetham 1985, 76.

85. See Ferguson 1990; and Nelson 1995.

86. Paris 1997. 
would otherwise have been the case. The result was operations that undermined the objectives of the mandate. ${ }^{87}$

Bureaucratic universalism. A second source of pathology in IOs derives from the fact that bureaucracies "orchestrate numerous local contexts at once." 88 Bureaucrats necessarily flatten diversity because they are supposed to generate universal rules and categories that are, by design, inattentive to contextual and particularistic concerns. Part of the justification for this, of course, is the bureaucratic view that technical knowledge is transferable across circumstances. Sometimes this is a good assumption, but not always; when particular circumstances are not appropriate to the generalized knowledge being applied, the results can be disastrous. ${ }^{89}$

Many critics of the IMF's handling of the Asian financial crises have argued that the IMF inappropriately applied a standardized formula of budget cuts plus high interest rates to combat rapid currency depreciation without appreciating the unique and local causes of this depreciation. These governments were not profligate spenders, and austerity policies did little to reassure investors, yet the IMF prescribed roughly the same remedy that it had in Latin America. The result, by the IMF's later admission, was to make matters worse. ${ }^{90}$

Similarly, many of those who worked in peacekeeping operations in Cambodia were transferred to peacekeeping operations in Bosnia or Somalia on the assumption that the knowledge gained in one location would be applicable to others. Although some technical skills can be transferred across contexts, not all knowledge and organizational lessons derived from one context are appropriate elsewhere. The UN has a longstanding commitment to neutrality, which operationally translates into the view that the UN should avoid the use of force and the appearance of partiality. This knowledge was employed with some success by UN envoy Yasushi Akashi in Cambodia. After his stint in Cambodia, he became the UN Special Representative in Yugoslavia. As many critics of Akashi have argued, however, his commitment to these rules, combined with his failure to recognize that Bosnia was substantially different from Cambodia, led him to fail to use force to defend the safe havens when it was appropriate and likely to be effective. ${ }^{91}$

Normalization of deviance. We derive a third type of pathology from Diane Vaughan's study of the space shuttle Challenger disaster in which she chronicles the way exceptions to rules (deviance) over time become routinized and normal parts of procedures. ${ }^{92}$ Bureaucracies establish rules to provide a predictable response to environmental stimuli in ways that safeguard against decisions that might lead to accidents and faulty decisions. At times, however, bureaucracies make small, calculated

87. See Featherston 1995; Chopra, Eknes, and Nordbo 1995; and Hirsch and Oakley 1995, chap. 6.

88. Heyman 1995, 262.

89. Haas 1990, chap. 3.

90. See Feldstein 1998; Radelet and Sachs 1999; and Kapur 1998.

91. Rieff 1996.

92. Vaughan 1996. 
deviations from established rules because of new environmental or institutional developments, explicitly calculating that bending the rules in this instance does not create excessive risk of policy failure. Over time, these exceptions can become the rule - they become normal, not exceptions at all: they can become institutionalized to the point where deviance is "normalized." The result of this process is that what at time $t_{1}$ might be weighed seriously and debated as a potentially unacceptable risk or dangerous procedure comes to be treated as normal at time $t_{\mathrm{n}}$. Indeed, because of staff turnover, those making decisions at a later point in time might be unaware that the now-routine behavior was ever viewed as risky or dangerous.

We are unaware of any studies that have examined this normalization of deviance in IO decision making, though one example of deviance normalization comes to mind. Before 1980 the UNHCR viewed repatriation as only one of three durable solutions to refugee crises (the others being third-country asylum and host-country integration). In its view, repatriation had to be both safe and voluntary because forced repatriation violates the international legal principle of nonrefoulement, which is the cornerstone of international refugee law and codified in the UNHCR's convention. Prior to 1980, UNHCR's discussions of repatriation emphasized that the principles of safety and voluntariness must be safeguarded at all costs. According to many commentators, however, the UNHCR has steadily lowered the barriers to repatriation over the years. Evidence for this can be found in international protection manuals, the UNHCR Executive Committee resolutions, and discourse that now weighs repatriation and the principle of nonrefoulement against other goals such a peace building. This was a steady and incremental development as initial deviations from organizational norms accumulated over time and led to a normalization of deviance. The result was a lowering of the barriers to repatriation and an increase in the frequency of involuntary repatriation. ${ }^{93}$

Insulation. Organizations vary greatly in the degree to which they receive and process feedback from their environment about performance. Those insulated from such feedback often develop internal cultures and worldviews that do not promote the goals and expectations of those outside the organization who created it and whom it serves. These distinctive worldviews can create the conditions for pathological behavior when parochial classification and categorization schemes come to define reality - how bureaucrats understand the world — such that they routinely ignore information that is essential to the accomplishment of their goals. ${ }^{94}$

Two causes of insulation seem particularly applicable to IOs. The first is professionalism. Professional training does more than impart technical knowledge. It actively seeks to shape the normative orientation and worldviews of those who are trained. Doctors are trained to value life above all else, soldiers are trained to sacri-

93. See Chimni 1993, 447; Amnesty International 1997a,b; Human Rights Watch 1997; Zieck 1997, 433, 434, 438-39; and Barbara Crossette, "The Shield for Exiles Is Lowered," The New York Times, 22 December 1996, 4-1.

94. See Berger and Luckman 1967, chap. 1; Douglas 1986; Bruner 1990; March and Olsen 1989; and Starr 1992. 
fice life for certain strategic objectives, and economists are trained to value efficiency. Bureaucracies, by their nature, concentrate professionals inside organizations, and concentrations of people with the same expertise or professional training can create an organizational worldview distinct from the larger environment. Second, organizations for whom "successful performance" is difficult to measure - that is, they are valued for what they represent rather than for what they do and do not "compete" with other organizations on the basis of output - are protected from selection and performance pressures that economistic models simply assume will operate. The absence of a competitive environment that selects out inefficient practices coupled with already existing tendencies toward institutionalization of rules and procedures insulates the organization from feedback and increases the likelihood of pathologies.

IOs vary greatly in the degree to which the professionals they recruit have distinctive worldviews and the degree to which they face competitive pressures, but it is clearly the case that these factors insulate some IOs to some degree and in so doing create a tendency toward pathology. The World Bank, for example, has been dominated for much of its history by economists, which, at least in part, has contributed to many critiques of the bank's policies. In one such critique James Ferguson opens his study of the World Bank's activity in Lesotho by comparing the bank's introductory description of Lesotho in its report on that country to facts on the ground; he shows how the bank "creates" a world that has little resemblance to what historians, geographers, or demographers see on the ground in Lesotho but is uniquely suited to the bank's organizational abilities and presents precisely the problems the bank knows how to solve. This is not simply "staggeringly bad scholarship," Ferguson argues, but a way of making the world intelligible and meaningful from a particular perspective - the World Bank's. ${ }^{95}$ The problem, however, is that this different worldview translates into a record of development failures, which Ferguson explores in detail.

Insulation contributes to and is caused by another well-known feature of organizations - the absence of effective feedback loops that allow the organization to evaluate its efforts and use new information to correct established routines. This is surely a "rational" procedure in any social task but is one that many organizations, including IOs, fail to perform. ${ }^{96}$ Many scholars and journalists, and even the current head of the World Bank, have noticed that the bank has accumulated a rather distinctive record of "failures" but continues to operate with the same criteria and has shown a marked lack of interest in evaluating the effectiveness of its own projects. ${ }^{97}$ The same is true of other IOs. Jarat Chopra observes that the lessons-learned conferences that were established after Somalia were structurally arranged so that no information could come out that would blemish the UN's record. Such attempts at face saving, Chopra cautions, make it more likely that these maladies will go uncorrected. ${ }^{98}$ Sometimes

95. Ferguson 1990, 25-73.

96. March and Olsen 1989, chap. 5; Haas 1990.

97. See Wade 1996, 14-17; Nelson 1995, chaps. 6, 7; and Richard Stevenson, "The Chief Banker for the Nations at the Bottom of the Heap," New York Times, 14 September 1997, sec. 3, 1, 12-14.

98. Chopra 1996. 
new evaluative criteria are hoisted in order to demonstrate that the failures were not really failures but successes.

Cultural contestation. Organizational coherence is an accomplishment rather than a given. Organizational control within a putative hierarchy is always incomplete, creating pockets of autonomy and political battles within the bureaucracy. ${ }^{99}$ This is partly a product of the fact that bureaucracies are organized around the principle of division-of-labor, and different divisions tend to be staffed by individuals who are "experts" in their assigned tasks. These different divisions may battle over budgets or material resources and so follow the bureaucratic politics model, but they may also clash because of distinct internal cultures that grow up inside different parts of the organization. Different segments of the organization may develop different ways of making sense of the world, experience different local environments, and receive different stimuli from outside; they may also be populated by different mixes of professions or shaped by different historical experiences. All of these would contribute to the development of different local cultures within the organization and different ways of perceiving the environment and the organization's overall mission. Organizations may try to minimize complications from these divisions by arranging these demands hierarchically, but to the extent that hierarchy resolves conflict by squelching input from some subunits in favor of others, the organization loses the benefits of a division of labor that it was supposed to provide. More commonly, though, attempts to reconcile competing worldviews hierarchically are simply incomplete. Most organizations develop overlapping and contradictory sets of preferences among subgroups. ${ }^{100}$ Consequently, different constituencies representing different normative views will suggest different tasks and goals for the organization, resulting in a clash of competing perspectives that generates pathological tendencies.

The existence of cultural contestation might be particularly true of high-profile and expansive IOs like the UN that have vague missions, broad and politicized constituencies, and lots of divisions that are developed over time and in response to new environmental demands. Arguably a number of the more spectacular debacles in recent UN peacekeeping operations might be interpreted as the product of these contradictions.

Consider the conflict between the UN's humanitarian missions and the value it places on impartiality and neutrality. Within the organization there are many who view impartiality as a core constitutive principle of UN action. On the one hand, the UN's moral standing, its authority, and its ability to persuade all rest on this principle. On the other hand, the principles of humanitarianism require the UN to give aid to those in need-values that are particularly strong in a number of UN relief and humanitarian agencies. These two norms of neutrality and humanitarian assistance, and the parts of the bureaucracy most devoted to them, come into direct conflict in those situations where providing humanitarian relief might jeopardize the UN's 
vaunted principle of neutrality. Bosnia is the classic case in point. On the one hand, the "all necessary means" provision of Security Council resolutions gave the UN authority to deliver humanitarian aid and protect civilians in the safe havens. On the other hand, the UN abstained from "taking sides" because of the fear that such actions would compromise its neutrality and future effectiveness. The result of these conflicts was a string of contradictory policies that failed to provide adequately for the UN's expanding humanitarian charges. ${ }^{101}$ According to Shashi Tharoor, a UN official intimately involved in these decisions, "It is extremely difficult to make war and peace with the same people on the same territory at the same time." 102

UNHCR provides another possible example of cultural contestation. Historically, the UNHCR's Protection Division has articulated a legalistic approach toward refugee matters and thus tends to view the UNHCR and itself as the refugee's lawyer and as the protector of refugee rights under international law. Those that inhabit the UNHCR's regional bureaus, however, have been characterized as taking a less "narrow" view of the organization's mission, stressing that the UNHCR must take into account the causes of refugee flows and state pressures. These cultural conflicts have been particularly evident, according to many observers, when the UNHCR contemplates a repatriation exercise in areas of political instability and conflict: protection officers demand that the refugees' rights, including the right of nonrefoulement, be safeguarded, whereas the regional bureaus are more willing to undertake a risky repatriation exercise if it might serve broader organizational goals, such as satisfying the interests of member states, and regional goals, such as facilitating a peace agreement. ${ }^{103}$

Although bureaucratic culture is not the only source of IO dysfunction, it is a potentially powerful one that creates broad patterns of behavior that should interest international relations scholars. None of the sources of pathologies sketched here is likely to appear in isolation in any empirical domain. These processes interact and feed on each other in ways that will require further theorizing and research. Moreover, while we have highlighted the organization's internal characteristics, we must always bear in mind that the external environment presses upon and shapes the internal characteristics of the organization in a host of ways. Cultural contestation within an organization frequently originates from and remains linked to normative contradictions in the larger environment. Demands from states can be extremely important determinants of IO behavior and may override internal cultural dynamics, but they can also set them in place if conflicting state demands result in the creation of organizational structures or missions that are prone to pathology. As we begin to explore dysfunctional and pathological behavior, we must bear in mind the complex relationship between different causal pathways, remaining closely attentive to both the internal organizational dynamics and the IO's environment.

101. See Barnett 1997a; David Rieff, "We Hate You,” New Yorker, 4 September 1995, 41-48; David Rieff, "The Institution That Saw No Evil," The New Republic, 12 February 1996, 19-24; and Rieff 1996.

102. Quoted in Weiss 1996, 85; also see Rieff 1996, 166, 170, 193.

103. See Kennedy 1986; and Lawyers Committee for Human Rights 1991. 


\section{Conclusion}

For all the attention international relations scholars have paid to international institutions over the past several decades, we know very little about the internal workings of IOs or about the effects they have in the world. Our ignorance, we suspect, is in large part a product of the theoretical lens we have applied. From an economistic perspective, the theoretically interesting question to ask about IOs is why they are created in the first place. Economists want to know why we have firms; political scientists want to know why we have IOs. In both cases, the question flows naturally from first theoretical principles. If you think that the world looks like a microeconomic market-anarchy, firms (or states) competing to maximize their utilitieswhat is anomalous and therefore theoretically interesting is cooperation. Consequently, our research tends to focus on the bargains states strike to make or reshape IOs. Scholars pay very little attention to what goes on subsequently in their day-today operations or even the larger effects that they might have on the world.

Viewing IOs through a constructivist or sociological lens, as we suggest here, reveals features of IO behavior that should concern international relations scholars because they bear on debates central to our field-debates about whether and how international institutions matter and debates about the adequacy of a statist ontology in an era of globalization and political change. Three implications of this alternative approach are particularly important. First, this approach provides a basis for treating IOs as purposive actors. Mainstream approaches in political science that are informed by economic theories have tended to locate agency in the states that comprise IO membership and treat IOs as mere arenas in which states pursue their policies. By exploring the normative support for bureaucratic authority in the broader international culture and the way IOs use that authority to construct the social world, we provide reasons why IOs may have autonomy from state members and why it may make sense analytically to treat them as ontologically independent. Second, by providing a basis for that autonomy we also open up the possibility that IOs are powerful actors who can have independent effects on the world. We have suggested various ways to think about how IOs are powerful actors in global politics, all of which encourage greater consideration of how IOs affect not only discrete outcomes but also the constitutive basis of global politics.

Third, this approach also draws attention to normative evaluations of IOs and questions what appears to us to be rather uncritical optimism about IO behavior. Contemporary international relations scholars have been quick to recognize the positive contributions that IOs can make, and we, too, are similarly impressed. But for all their desirable qualities, bureaucracies can also be inefficient, ineffective, repressive, and unaccountable. International relations scholars, however, have shown little interest in investigating these less savory and more distressing effects. The liberal Wilsonian tradition tends to see IOs as promoters of peace, engines of progress, and agents for emancipation. Neoliberals have focused on the impressive way in which IOs help states to overcome collective action problems and achieve durable cooperation. Realists have focused on their role as stabilizing forces in world politics. Constructivists, 
too, have tended to focus on the more humane and other-regarding features of IOs, but there is nothing about social construction that necessitates "good" outcomes. We do not mean to imply that IOs are "bad"; we mean only to point out theoretical reasons why undesirable behavior may occur and suggest that normative evaluation of IO behavior should be an empirical and ethical matter, not an analytic assumption.

\section{References}

Alger, Chadwick. 1963. United Nations Participation as a Learning Process. Public Opinion Quarterly 27 (3):411-26.

Allison, Graham. 1971. Essence of Decision. Boston: Little, Brown.

Alvesson, Mats. 1996. Cultural Perspectives on Organizations. New York: Cambridge University Press. Amnesty International. 1997a. In Search of Safety: The Forcibly Displaced and Human Rights in Africa. AI Index, 20 June, AFR 01/05/97. Available from < www.amnesty.org/ailib/aipub/1997/10100597.htm >. 1997b. Rwanda: Human Rights Overlooked in Mass Repatriation. Available from <www. amnesty.org/ailib/aipub/1997/AFR/147002797.htm>.

Anonymous. 1997. The UNHCR Note on International Protection You Won't See. International Journal of Refugee Law 9 (2):267-73.

Arendt, Hannah. 1977. Eichmann in Jerusalem: A Report on the Banality of Evil. New York: Penguin.

Ascher, William. 1983. New Development Approaches and the Adaptability of International Agencies: The Case of the World Bank. International Organization 37 (3):415-39.

Ayres, Robert L. 1983. Banking on the Poor: The World Bank and World Poverty. Cambridge, Mass.: MIT Press.

Baldwin, David, ed. 1993. Neorealism and Neoliberalism. New York: Columbia University Press.

Barnett, Michael. 1997a. The Politics of Indifference at the United Nations and Genocide in Rwanda and Bosnia. In This Time We Knew: Western Responses to Genocide in Bosnia, edited by Thomas Cushman and Stjepan Mestrovic, 128-62. New York: New York University Press.

. 1997b. The UN Security Council, Indifference, and Genocide in Rwanda. Cultural Anthropology 12 (4):551-78.

Beetham, David. 1985. Max Weber and the Theory of Modern Politics. New York: Polity.

1996. Bureaucracy. 2d ed. Minneapolis: University of Minnesota Press.

Bendor, Jonathan, and Thomas Hammond. 1992. Rethinking Allison's Models. American Political Science Review 82 (2):301-22.

Berger, Peter, and Thomas Luckmann. 1966. The Social Construction of Reality. New York: Doubleday.

Blumer, Herbert. 1969. Symbolic Interactionism: Perspective and Method. Englewood Cliffs, N.J.: PrenticeHall.

Bourdieu, Pierre. 1994. On Symbolic Power. In Language and Symbolic Power, edited by Pierre Bourdieu, 163-70. Chicago: University of Chicago Press.

Boutros-Ghali, Boutros. 1995. Agendafor Peace. 2d ed. New York: UN Press.

1996a. Global Leadership After the Cold War. Foreign Affairs 75:86-98.

1996b. Agenda for Democratization. New York: UN Press.

Bruner, Jerome. 1990. Acts of Meaning. Cambridge, Mass.: Harvard University Press.

Burley, Anne-Marie, and Walter Mattli. 1993. Europe Before the Court: A Political Theory of Integration. International Organization 47 (1):41-76.

Burrell, Gibson, and Gareth Morgan. 1979. Sociological Paradigms and Organizational Analysis. London: Heinemman.

Call, Chuck, and Michael Barnett. Forthcoming. Looking for a Few Good Cops: Peacekeeping, Peacebuilding, and U.N. Civilian Police. International Peacekeeping. 
Campbell, John. 1998. Institutional Analysis and the Role of Ideas in Political Economy. Theory and Society 27:377-409.

Carr, Edward H. [1939] 1964. The Twenty Year's Crisis. New York: Harper Torchbooks.

Chimni, B. 1993. The Meaning of Words and the Role of UNHCR in Voluntary Repatriation. International Journal of Refugee Law 5 (3):442-60.

Chopra, Jarat. 1996. Fighting for Truth at the UN. Crosslines Global Report, 26 November, 7-9.

Chopra, Jarat, Age Eknes, and Toralv Nordbo. 1995. Fighting for Hope in Somalia. Oslo: NUPI.

Claude, Inis L., Jr. 1966. Collective Legitimization as a Political Function of the United Nations. International Organization 20 (3):337-67.

Clegg, Stewart. 1994a. Power and Institutions in the Theory of Organizations. In Toward a New Theory of Organizations, edited by John Hassard and Martin Parker, 24-49. New York: Routledge.

. 1994b. Weber and Foucault: Social Theory for the Study of Organizations. Organization 1 (1): 149-78.

Coase, Ronald. 1937. The Nature of the Firm. Economica 4 (November):386-405.

Commission on Global Governance. 1995. Our Global Neighborhood. New York: Oxford University Press.

Cooper, Frederick, and Randy Packard, eds. 1998. International Development and the Social Sciences. Berkeley: University of California Press.

Cox, Robert. 1980. The Crisis of World Order and the Problem of International Organization in the 1980s. International Journal 35 (2):370-95.

-1992. Multilateralism and World Order. Review of International Studies 18 (2):161-80.

1996. The Executive Head: An Essay on Leadership in International Organization. In Approaches to World Order, edited by Robert Cox, 317-48. New York: Cambridge University Press.

Cox, Robert, and Harold Jacobson. 1977. Decision Making. International Social Science Journal 29 (1):115-33.

Cox, Robert, Harold Jacobson, Gerard Curzon, Victoria Curzon, Joseph Nye, Lawrence Scheinman, James Sewell, and Susan Strange. 1974. The Anatomy of Influence: Decision Making in International Organization. New Haven, Conn.: Yale University Press.

Deutsch, Karl. 1963. The Nerves of Government: Models of Political Communication and Control. Glencoe, Ill.: Free Press.

Dillon, Patricia, Thomas Ilgen, and Thomas Willett. 1991. Approaches to the Study of International Organizations: Major Paradigms in Economics and Political Science. In The Political Economy of International Organizations: A Public Choice Approach, edited by Ronald Vaubel and Thomas Willett, 79-99. Boulder, Colo.: Westview Press.

DiMaggio, Paul J., and Walter W. Powell. 1983. The Iron Cage Revisited: Institutional Isomorphism and Collective Rationality in Organizational Fields. American Sociological Review 48:147-60.

Dobbin, Frank. 1994. Cultural Models of Organization: The Social Construction of Rational Organizing Principles. In The Sociology of Culture, edited by Diana Crane, 117-42. Boston: Basil Blackwell.

Douglas, Mary. 1986. How Institutions Think. Syracuse, N.Y.: Syracuse University Press.

Doyle, Michael. 1997. Ways of War and Peace. New York: Norton.

Escobar, Arturo. 1995. Encountering Development: The Making and Unmaking of the Third World. Princeton, N.J.: Princeton University Press.

Featherston, A. B. 1995. Habitus in Cooperating for Peace: A Critique of Peacekeeping. In The New Agenda for Global Security: Cooperating for Peace and Beyond, edited by Stephanie Lawson, 101-18. St. Leonards, Australia: Unwin and Hyman.

Feld, Werner J., and Robert S. Jordan, with Leon Hurwitz. 1988. International Organizations: A Comparative Approach. 2d ed. New York: Praeger.

Feldstein, Martin. 1998. Refocusing the IMF. Foreign Affairs 77 (2):20-33.

Ferguson, James. 1990. The Anti-Politics Machine: "Development," Depoliticization, and Bureaucratic Domination in Lesotho. New York: Cambridge University Press.

Finnemore, Martha. 1993. International Organizations as Teachers of Norms: The United Nations Educational, Scientific, and Cultural Organization and Science Policy. International Organization 47: 565-97. 
1996a. Norms, Culture, and World Politics: Insights from Sociology's Institutionalism. International Organization 50 (2):325-47.

1996b. National Interests in International Society. Ithaca, N.Y.: Cornell University Press.

Fisher, William. 1997. Doing Good? The Politics and Antipolitics of NGO Practices. Annual Review of Anthropology 26:439-64.

Foucault, Michel. 1977. Discipline and Punish. New York: Vintage Press.

Gallaroti, Guilio. 1991. The Limits of International Organization. International Organization 45 (2):183220.

Gerth, H. H., and C. Wright Mills. 1978. From Max Weber: Essays in Sociology. New York: Oxford University Press.

Goodwin-Gill, Guy. 1996. Refugee in International Law. New York: Oxford Clarendon.

Gran, Guy. 1986. Beyond African Famines: Whose Knowledge Matters? Alternatives 11:275-96.

Grandori, Anna. 1993. Notes on the Use of Power and Efficiency Constructs in the Economics and Sociology of Organizations. In Interdisciplinary Perspectives on Organizational Studies, edited by S. Lindenberg and H. Schreuder, 61-78. New York: Pergamon

Gupta, Akhil. 1998. Postcolonial Developments: Agriculture in the Making of Modern India. Durham, N.C.: Duke University Press.

Haas, Ernst. 1990. When Knowledge Is Power. Berkeley: University of California Press.

Haas, Ernst, and Peter Haas. 1995. Learning to Learn: Improving International Governance. Global Governance 1 (3):255-85.

Haas, Peter, ed. 1992. Epistemic Communities. International Organization 46 (1). Special issue.

Handelman, Don. 1995. Comment. Current Anthropology 36 (2):280-81.

Harrell-Bond, Barbara. 1989. Repatriation: Under What Conditions Is It the Most Desirable Solution for Refugees? African Studies Review 32 (1):41-69.

Hartigan, Kevin. 1992. Matching Humanitarian Norms with Cold, Hard Interests: The Making of Refugee Policies in Mexico and Honduras, 1980-89. International Organization 46:709-30.

Helms, Jesse. 1996. Saving the UN. Foreign Affairs 75 (5):2-7.

Hendrie, Barbara. 1997. Knowledge and Power: A Critique of an International Relief Operation. Disasters 21 (1):57-76.

Heyman, Josiah McC. 1995. Putting Power in the Anthropology of Bureaucracy. Current Anthropology36 (2):261-77.

Hirsch, John, and Robert Oakley. 1995. Somalia and Operation Restore Hope: Reflections on Peacemaking and Peacekeeping. Washington, D.C.: USIP Press.

Human Rights Watch. 1997. Uncertain Refuge: International Failures to Protect Refugees. Vol. 1, no. 9 (April).

Hurrell, Andrew, and Ngaire Woods. 1995. Globalisation and Inequality. Millennium 24 (3):447-70.

Immergut, Ellen. 1998. The Theoretical Core of the New Institutionalism. Politics and Society 26 (1): $5-34$.

Jackson, Robert. 1993. The Weight of Ideas in Decolonization: Normative Change in International Relations. In Ideas and Foreign Policy, edited by Judith Goldstein and Robert O. Keohane, 111-38. Ithaca, N.Y.: Cornell University Press.

Jacobson, Harold. 1979. Networks of Interdependence. New York: Alfred A. Knopf.

Joint Evaluation of Emergency Assistance to Rwanda. 1996. The International Response to Conflict and Genocide: Lessons from the Rwanda Experience. 5 vols. Copenhagen: Steering Committee of the Joint Evaluation of Emergency Assistance to Rwanda.

Kapur, Devesh. 1998. The IMF: A Cure or a Curse? Foreign Policy 111:114-29.

Katzenstein, Peter J., ed. 1996. The Culture of National Security: Identity and Norms in World Politics. New York: Columbia University Press.

Keck, Margaret, and Kathryn Sikkink. 1998. Activists Beyond Borders. Ithaca, N.Y.: Cornell University Press.

Keeley, James. 1990. Toward a Foucauldian Analysis of International Regimes. International Organization 44 (1):83-105. 
Keen, David. 1994. The Benefits of Famine: A Political Economy of Famine and Relief in Southwestern Sudan, 1983-89. Princeton, N.J.: Princeton University Press

Kennedy, David. 1986. International Refugee Protection. Human Rights Quarterly 8:1-9.

Keohane, Robert O. 1984. After Hegemony. Princeton, N.J.: Princeton University Press.

Kiewiet, D. Roderick, and Matthew McCubbins. 1991. The Logic of Delegation. Chicago: University of Chicago Press.

Krasner, Stephen D. 1991. Global Communications and National Power: Life on the Pareto Frontier. World Politics 43 (3):336-66.

. 1983a. Regimes and the Limits of Realism: Regimes as Autonomous Variables. In International Regimes, edited by Stephen Krasner, 355-68. Ithaca, N.Y.: Cornell University Press.

Krasner, Stephen D., ed. 1983b. International Regimes. Ithaca, N.Y.: Cornell University Press.

Krause, Keith, and Michael Williams. 1996. Broadening the Agenda of Security Studies: Politics and Methods. Mershon International Studies Review 40 (2):229-54.

Lake, David. 1996. Anarchy, Hierarchy, and the Variety of International Relations. International Organization $50(1): 1-34$.

Lawyers Committee for Human Rights. 1991. General Principles Relating to the Promotion of Refugee Repatriation. New York: Lawyers Committee for Human Rights.

Legro, Jeffrey. 1997. Which Norms Matter? Revisiting the "Failure" of Internationalism. International Organization 51 (1):31-64.

Lipartito, Kenneth. 1995. Culture and the Practice of Business History. Business and Economic History $24(2): 1-41$.

Lipson, Michael. 1999. International Cooperation on Export Controls: Nonproliferation, Globalization, and Multilateralism. Ph.D. diss., University of Wisconsin, Madison.

Malkki, Liisa. 1996. Speechless Emissaries: Refugees, Humanitarianism, and Dehistoricization. Cultural Anthropology 11 (3):377-404.

March, James. 1988. Decisions and Organizations. Boston: Basil Blackwell.

- 1997. Understanding How Decisions Happen in Organizations. In OrganizationalDecision Making, edited by Z. Shapira, 9-33. New York: Cambridge University Press.

March, James, and Johan P. Olsen. 1989. Rediscovering Institutions: The Organizational Basis of Politics. New York: Free Press.

Martin, Joan. 1992. Cultures in Organizations: Three Perspectives. New York: Oxford University Press.

Matthews, Jessica Tuchman. 1989. Redefining Security. Foreign Affairs 68 (2):162-77.

McNeely, Connie. 1995. Constructing the Nation-State: International Organization and Prescriptive Action. Westport, Conn.: Greenwood Press.

Mearsheimer, John. 1994. The False Promise of International Institutions. International Security 19 (3): $5-49$.

Meyer, John W., and Brian Rowan. 1977. Institutionalized Organizations: Formal Structure as Myth and Ceremony. American Journal of Sociology 83:340-63.

Meyer, John W., and W. Richard Scott. 1992. Organizational Environments: Ritual and Rationality. Newbury Park, Calif.: Sage.

Meyer, Marshall, and Lynne Zucker. 1989. Permanently Failing Organizations. Newbury Park: Sage Press.

Miller, Gary, and Terry M. Moe. 1983. Bureaucrats, Legislators, and the Size of Government. American Political Science Review 77 (June):297-322.

Moe, Terry M. 1984. The New Economics of Organization. American Journal of Political Science 28: 739-77.

Moravcsik, Andrew. 1997. Taking Preferences Seriously: Liberal Theory and International Politics. International Organization 51 (4):513-54.

- 1999. A New Statecraft? Supranational Entrepreneurs and International Cooperation. International Organization 53 (2):267-306.

Mouzelis, Nicos. 1967. Organization and Bureaucracy. Chicago: Aldine.

Murphy, Craig. 1994. International Organizations and Industrial Change. New York: Oxford University Press. 
Nelson, Paul. 1995. The World Bank and Non-Governmental Organizations. New York: St. Martin's Press. Ness, Gayl, and Steven Brechin. 1988. Bridging the Gap: International Organizations as Organizations. International Organization 42 (2):245-73.

Niskanen, William A. 1971. Bureaucracy and Representative Government. Chicago: Aldine.

Paris, Roland. 1997. Peacebuilding and the Limits of Liberal Internationalism. International Security 22 (2):54-89.

Perry, William. 1996. Defense in an Age of Hope. Foreign Affairs 75 (6):64-79.

Pollack, Mark. 1997. Delegation, Agency, and Agenda-Setting in the European Community. International Organization 51 (1):99-134.

Powell, Walter W., and Paul J. DiMaggio, eds. 1991. The New Institutionalism in OrganizationalAnalysis. Chicago: University of Chicago Press.

Pratt, John, and Richard J. Zeckhauser. 1985. Principals and Agents: The Structure of Business. Boston: Harvard Business School Press.

Price, Richard. 1997. The Chemical Weapons Taboo. Ithaca, N.Y.: Cornell University Press.

Radelet, Steven, and Jeffrey Sach. 1999. What Have We Learned, So Far, From the Asian Financial Crisis?

Harvard Institute for International Development, 4 January. Available from <www.hiid.harvard.edu/ pub/other/aea122.pdf>.

Rieff, David. 1996. Slaughterhouse. New York: Simon and Schuster.

Rittberger, Volker, ed. 1993. Regime Theory and International Relations. Oxford: Clarendon Press.

Ross, George. 1995. Jacques Delors and European Integration. New York: Oxford University Press.

Ruggie, John. 1996. Winning the Peace. New York: Columbia University Press.

. 1998. What Makes the World Hang Together. International Organization 52 (3):855-86.

Sandholtz, Wayne. 1993. Choosing Union: Monetary Politics and Maastricht. International Organization 47: $1-40$.

Sagan, Scott. 1993. The Limits of Safety: Organizations, Accidents, and Nuclear Weapons. Princeton, N.J.: Princeton University Press.

Schaar, John. 1984. Legitimacy in the Modern State. In Legitimacy and the State, edited by William Connolly, 104-33. Oxford: Basil Blackwell.

Schien, Edgar. 1996. Culture: The Missing Concept in Organization Studies. Administrative Studies Quarterly 41:229-40.

Scott, W. Richard. 1992. Organizations: Rational, Natural, and Open Systems. 3d ed. Englewood Cliffs, N.J.: Prentice-Hall.

Shanks, Cheryl, Harold K. Jacobson, and Jeffrey H. Kaplan. 1996. Inertia and Change in the Constellation of Intergovernmental Organizations, 1981-1992. International Organization 50 (4):593-627.

Shapira, Zur, ed. 1997. Organizational Decision. New York: Cambridge University Press.

Shore, Cris, and Susan Wright. 1997. Policy: A New Field of Anthropology. In Anthropology of Policy: Critical Perspectives on Governance and Power, edited by Cris Shore and Susan Wright, 3-41. New York: Routledge Press.

Sigelman, Lee. 1986. The Bureaucratic Budget Maximizer: An Assumption Examined. Public Budgeting and Finance (spring):50-59.

Snidal, Duncan. 1996. Political Economy and International Institutions. International Review of Law and Economics 16:121-37.

Starr, Paul. 1992. Social Categories and Claims in the Liberal State. In How Classification Works: Nelson Goodman Among the Social Sciences, edited by Mary Douglas and David Hull, 154-79. Edinburgh: Edinburgh University Press.

Strange, Susan. 1997. The Retreat of the State. New York: Cambridge University Press.

Thomas, Daniel C. Forthcoming. The Helsinki Effect: International Norms, Human Rights, and Demise of Communism. Princeton, N.J.: Princeton University Press.

UN Development Program. 1994. Human Development Report 1994. New York: Oxford University Press.

UN Peacekeeping Missions. 1994. The Lessons from Cambodia. Asia Pacific Issues, Analysis from the East-West Center, No. 11, March. 
Vaubel, Roland. 1991. A Public Choice View of International Organization. In The Political Economy of International Organizations, edited by Roland Vaubel and Thomas Willett, 27-45. Boulder, Colo.: Westview Press.

Vaughan, Diane. 1996. The Challenger Launch Decision. Chicago: University of Chicago Press.

Wade, Robert. 1996. Japan, the World Bank, and the Art of Paradigm Maintenance: The East Asian Miracle in Political Perspective. New Left Review 217:3-36.

Walkup, Mark. 1997. Policy Dysfunction in Humanitarian Organizations: The Role of Coping Strategies, Institutions, and Organizational Culture. Journal of Refugee Studies 10 (1):37-60.

Waltz, Kenneth. 1979. Theory of International Politics. Reading, Mass.: Addison-Wesley.

Wapner, Paul. 1996. Environmental Activism and World Civic Politics. Albany: State University of New York Press.

Weber, Max. 1947. Theory of Social and Economic Organization. New York: Oxford University Press.

- [1930] 1968. The Protestant Ethic and the Spirit of Capitalism. New York: Routledge.

1978. Bureaucracy. In From Max Weber: Essays in Sociology, edited by H. H. Gerth and C. Wright Mills, 196-44. New York: Oxford

Weber, Steven. Origins of the European Bank for Reconstruction and Development. International Organization 48(1):1-38.

Weingast, Barry R., and Mark Moran. 1983. Bureaucratic Discretion or Congressional Control: Regulatory Policymaking by the Federal Trade Commission. Journal of Political Economy 91 (October):765800 .

Weiss, Thomas. 1996. Collective Spinelessness: U.N. Actions in the Former Yugoslavia. In The World and Yugoslavia's Wars, edited by Richard Ullman, 59-96. New York: Council on Foreign Relations Press.

Weiss, Tom, and Amir Pasic. 1997. Reinventing UNHCR: Enterprising Humanitarians in the Former Yugoslavia, 1991-95. Global Governance 3 (1):41-58.

Wendt, Alexander. 1995. Constructing International Politics. International Security 20 (1):71-81.

. 1998. Constitution and Causation in International Relations. Review of International Studies 24 (4):101-17. Special issue.

Williams, Michael. 1996. Hobbes and International Relations: A Reconsideration. International Organization 50 (2):213-37.

Williamson, Oliver. 1975. Markets and Hierarchies, Analysis and Antitrust Implications: A Study in the Economics of Internal Organization. New York: Free Press.

- 1985. The Economic Institutions of Capitalism: Firms, Markets, Relational Contracting. New York: Free Press.

World Conference on Human Rights. 1993. Vienna Declaration on Human Rights, adopted 14-25 June. UN Document A/CONF.157/24 (Part I), 20; A/CONF.157/23 DPI/1394/Rev.1 DPI/1676 (95.I.21), 448; DPI/1707 ST/HR/2/Rev.4, 383.

Wright, Susan. 1994. "Culture" in Anthropology and Organizational Studies. In Anthropology of Organizations, edited by Susan Wright, 1-31. New York: Routledge.

Zabusky, Stacia. 1995. Launching Europe. Princeton, N.J.: Princeton University Press.

Zieck, Marjoleine. 1997. UNHCR and Voluntary Repatriation of Refugees: A Legal Analysis. The Hague: Martinus Nijhoff. 